\title{
KEPUTUSAN MENGGUNAKAN JASA BENGKEL MOBIL DI KABUPATEN MANOKWARI: PERAN KUALITAS LAYANAN, FAKTOR INDIVIDUAL, DAN LINGKUNGAN
}

\author{
Louis Soemadi Bopeng \\ Universitas Papua \\ louisbopeng@gmail.com
}

\begin{abstract}
The workshop business in Manokwari has a phenomenon or a tendency for consumers or motorized vehicle owners to be disappointed when using the service of a repair shop because it does not match their expectations. The purpose of this study based on the formulation of the problem above is to determine the effect of service quality factors, individual factors, environmental factors on purchasing decisions. Also, the dominant factor influences. A sample of 118 respondents with the criteria of owning a four-wheeled motorized vehicle or more and having used a repair shop to maintain or repair their vehicle. The data collection method in this study is a survey method using a structured questionnaire. The data analysis method used is descriptive statistical methods and inferential statistical methods. An interesting finding from this study is that the results of the study prove that the factors that have the greatest influence on consumer purchasing decisions are environmental factors. This is considered rational for researchers because of the high sense of solidarity and concern among the Manokwari people plays an important role in their purchasing decision making. Opinions from friends become the main reference in making repair shop service decisions because they assume that Terman or the reference group has visited the workshop and they think the workshop is able to meet their expectations. Therefore, with a reference from a friend, they no longer experience confusion and spend time and money deciding which workshop to visit to purchase repair shop services.
\end{abstract}

Keywords: repair; shop service quality; West Papua.

\section{PENDAHULUAN}

Manokwari merupakan Ibukota dari Provinsi Papua Barat, yang secara geografis berada di ujung Timur dari Indonesia (manokwarikab.go.id, 2018). Dari hasil observasi terhadap perkembangan bisnis di Manokwari, Manokwari memiliki banyak usaha bengkel dengan skala kecil ataupun besar. Sektor usaha bengkel mobil masih memiliki peluang yang cukup besar dikarenakan terdapat pertumbuhan penjualan mobil dan pertumbuhan minat konsumen untuk melakukan perawatan dan pemeliharaan mobil. Sehingga sektor usaha jasa bengkel mobil selain dituntut untuk menyediakan pelayanan jasa umum, juga dituntut pelayanan khusus yang tentunya memerlukan keahlian khusus untuk dapat bersaing dengan usaha bengkel lainnya. Pelayanan khusus tersebut tidak terbatas pada masalah teknis semata, tetapi juga menyangkut kenyamanan konsumen dari aspek non teknis.

Implikasi penting dari fenomena ini adalah makin tingginya tingkat persaingan, sehingga diperlukan manajemen pemasaran jasa yang berbeda dengan pemasaran tradisional (barang) yang telah dikenal selama ini. Pemasaran jasa merupakan suatu proses mempersepsikan, memahami, menstimulasi dan memenuhi kebutuhan pasar sasaran yang dipilih secara khusus dengan menyalurkan sumber-sumber sebuah organisasi untuk memenuhi kebutuhan tersebut (Tjiptono, 2009). Hal ini sejalan dengan apa yang dinyatakan oleh Lovelock (2002) bahwa sektor jasa merupakan sektor yang paling besar mengalami perubahan sebagai akibat dari cepatnya perubahan yang dialami oleh faktor lain. Organisasi yang akan survive dalam bisnisnya dituntut untuk melakukan pengelolaan usaha secara lebih efisien dan efektif dibandingkan dengan pesaingnya. Pada akhirnya mereka yang mampu bertahan bahkan yang menang dalam persaingan adalah mereka yang mampu bersaing secara efektif dan efisien serta menerapkan serangkaian strategi yang tepat dalam melayani kebutuhan, keinginan, dan harapan dari pelanggannya.

Hasil observasi awal menunjukkan bahwa untuk menciptakan keunikan atau ciri khas, akhir-akhir ini banyak bengkel mulai mencuat ke permukaan dan memunculkan istilah "car saloon" bahkan ada yang 
Louis Soemadi Bopeng. Keputusan Menggunakan Jasa Bengkel Mobil di Kabupaten Manokwari: Peran Kualitas Layanan, Faktor Individual, dan Lingkungan

memberikan nama "car spa" mengambil istilah dunia kecantikan wanita, yang pada intinya menawarkan fasiltas dan kenyamanan plus pada konsumen. Usaha jasa bengkel mobil ini tidak hanya menciptakan kenyamanan pada konsumen pria, tetapi juga untuk kaum wanita dan anak-anak. Bengkel-bengkel tersebut berkompetisi dalam meraih pelanggan dengan memberikan layanan terbaik. Dengan memfokuskan diri pada pelayanan jasa perawatan maupun perbaikan kendaraan bermotor baik untuk mobil keluaran lama maupun baru dengan baik dan benar, diharapkan bengkel-bengkel tersebut tetap bertahan, berkembang, dan terus melakukan inovasi.

Semakin berkembangnya usaha jasa bengkel ini di satu sisi membawa keuntungan bagi konsumen karena lebih banyak pilihan tempat bagi mereka untuk merawat maupun memperbaiki kendaraannya, tapi di sisi lain menimbulkan masalah bagi pengusaha bengkel tersebut untuk menghadapi persaingan yang ketat dalam memperebutkan jumlah konsumen yang berkunjung untuk merawat atau memperbaiki kendaraannya dan mempertahankan agar pelanggan tetap loyal pada bengkelnya. Oleh karena itu, pihak bengkel perlu menciptakan strategi-strategi yang lebih kompetitif untuk menghadapi persaingan yang ketat agar usaha dapat bertahan dan berkembang.

Berdasarkan observasi awal, konsumen akan memilih bengkel yang handal yang dapat memberikan kepuasan, di mana konsumen akan membandingkan besarnya total biaya yang dikeluarkan dengan besarnya total manfaat dalam menjadikan kendaraan tersebut tetap prima. Konsumen akan membentuk suatu harapan-harapan yang didasarkan pada pengalaman masa lalu, opini teman sejawat, informasi dari pembeli dan pesaing, serta janji-janji dari pihak bengkel. Dengan demikian, konsumen otomotif akan semakin kritis dalam menentukan dan memilih suatu bengkel untuk melakukan perawatan atau perbaikan kendaraannya. Sehingga, kunci sukses dalam memenangkan persaingan terletak pada kemampuan setiap perusahaan dalam memberikan kepuasan kepada para pelanggannya. Oleh karena itu evaluasi terhadap pelayanan jasa bengkel perlu dilakukan secara terus-menerus oleh pengelola maupun pemilik, salah satu caranya dengan menggunakan pendekatan konsumen (userbased approach).

Oleh karena itu, jasa yang diberikan oleh bengkel, perlu mengedepankan pelayanan kepada konsumen. Bengkel yang ingin meningkatkan kualitas pelayanannya tentunya perlu memperhatikan apa yang diinginkan bagi kepuasan konsumen, misalnya prosedur penerimaan konsumen yang mudah dan cepat, tindakan yang cepat saat konsumen membutuhkan bantuan untuk melakukan perbaikan atau perawatan kendaraannya, jaminan keamanan selama pelayanan dan kepercayaan terhadap pelayanan, adanya perhatian terhadap keluhan konsumen, dan perhatian pada tampilan fisik dari proses produksi.

Selain kualitas jasa yang ditawarkan pihak bengkel, menurut Nasikan dan Sasmit (2013), ada dimensi faktor internal dan eksternal yang memengaruhi perilaku konsumen. Faktor internal seperti pengalaman, belajar, kepribadian dan konsep diri, motivasi, sikap serta persepsi, dan faktor eksternal seperti budaya, sub-budaya, kelas sosial, kelompok referensi, keluarga, ekonomi serta bauran pemasaran. faktor eksternal meliputi budaya, sosial, referensi dan situasi. Dengan adanya dimensidimensi yang dapat memengaruhi perilaku konsumen dalam mengambil keputusan pembelian, pihak bengkel perlu melakukan kajian yang komprehensif apakah metode yang digunakan telah sesuai atau perlu dimodifikasi agar strategi yang dilakukan pihak bengkel dapat memenuhi kebutuhan, keinginan, dan harapan setiap konsumen.

Salah satu hal penting dalam pengembangan pemikiran bisnis yang memiliki keunggulan adalah mengenali konsumen dalam pengambilan keputusan pembelian (Dinawan, 2010). Perusahaan jasa bengkel adalah perusahaan penyedia jasa sehingga penting bagi pemasar untuk memahami bagaimana perilaku konsumen dalam usaha memuaskan kebutuhan dan keinginannya. Permasalahan yang ada sehubungan dengan penelitian ini dan berdasarkan pengamatan di lapangan yang menunjukkan adanya fenomena atau kecenderungan konsumen atau pemilik kendaraan bermotor akan merasa kecewa ketika menggunakan jasa bengkel dan hasilnya atau produk yag dihasilkan tidak sesuai dengan harapan. Hal ini didukung oleh hasil penelitian yang menyatakan bahwa bentuk bisnis yang produknya mampu mewakili harapan suatu masyarakat tertentu maka akan menjadi pilihan utama 
masyarakat tersebut dan bahkan lambat laun akan menggeser pilihan terhadap produk-produk sebelumnya (Widiasih, 2003). Berdasarkan beberapa pernyataan diatas, banyak faktor yang memengaruhi konsumen dalam mengambil keputusan pembelian barang atau jasa sehingga menimbulkan perilaku pembelian yang sangat kompleks untuk dipelajari. Sehingga, manajer atau pemilik usaha harus memahami bagaimana perilaku konsumen dalam melakukan pembelian barang atau jasa yang dihasilkan perusahaan.

Konsumen di Manokwari hidup di lingkungan yang kompleks dalam artian terdapat berbagai jenis produk barang atau jasa yang ditawarkan, serta tipe individu yang heterogen. Lingkungan dimana konsumen berada akan mempengaruhi perilaku konsumen tersebut dalam membeli suatu produk atau jasa baik secara langsung maupun tidak langsung. Menurut Engel., (2001), perilaku proses keputusan pembelian konsumen dipengaruhi oleh faktor lingkungan yang terdiri dari aspek budaya, kelas sosial, kelompok referensi dan keluarga. Lingkungan dalam penelitian ini, merupakan rangsangan fisik dan sosial yang dapat mempengaruhi afeksi dan kognisi serta perilaku konsumen dalam pengambilan keputusan pembelian yang terbentuk dari budaya, kelas sosial, kelompok referensi dan keluarga.

Keunggulan suatu produk jasa tergantung keunikan serta kualitas yang diperlihatkan oleh jasa tersebut. Menurut Fatihudin (2019) Jasa secara spesifik harus bersifat market oriented serta memperhatikan kebutuhan dan keinginan pelanggan karena jasa yang dirasakan dan dinikmati langsung oleh pelanggan akan segera mendapat penilaian sesuai atau tidak sesuai dengan harapan dan keinginan pelanggan. Oleh karena itu, keputusan tidak hanya didasarkan pada alasan rasional atau ekonomi, tetapi juga ada pengaruh lain, yaitu karakteristik individu (motivasi, persepsi, pengetahuan, kepribadian dan sikap). Dengan semakin beragamnya strategi usaha jasa bengkel yang ditawarkan, membuat konsumen dapat memilih usaha jasa bengkel yang paling sesuai dengan pertimbanganpertimbangan konsumen untuk memperoleh kepuasan.

Tujuan dari penelitian ini adalah untuk menganalisis pengaruh kualitas layanan, individual, dan lingkungan terhadap keputusan menggunakan jasa bengkel mobil di Kabupaten Manokwari.

\section{KAJIAN PUSTAKA DAN PENGEMBANGAN HIPOTESIS}

\section{Keputusan Menggunakan Produk Jasa}

Stanton (2002) mengemukakan bahwa jasa merupakan suatu yang tidak berwujud, yang dapat memberikan kepuasan kepada konsumen karena keinginan mereka. Untuk memproduksi jasa tersebut dapat menggunakan bantuan produksi fisik, namun dapat juga tidak. Selain itu, pada umumnya dikonsumsi bersamaan pada saat produksi, dan jasa tidak mengakibatkan perpindahan kepemilikan secara fisik. Keputusan menggunakan produk merupakan keputusan pembelian produk. Dimana produk terbagi dua yaitu barang dan jasa.

Menurut Schiffman dan Kanuk (2004) Pengambilan keputusan oleh konsumen merupakan suatu kegiatan individu yang secara langsung terlibat dalam mendapatkan dan mempergunakan barang yang ditawarkan. Proses pengambilan keputusan melibatkan tiga tahapan, antara lain: input, process, dan output. Tahapan input mempengaruhi rekognisi terhadap kebutuhan produk, tahapan process fokus terhadap bagaimana konsumen membuat keputusan dan tahapan output merupakan pembelian dan perilaku setelah pembelian. Keputusan pembelian diukur dengan menggunakan tiga indikator, yaitu sebagai berikut.

(1) Kesesuaian harapan atas produk yang dibeli (Y1.1), adalah adanya kesesuaian harapan konsumen terhadap jasa bengkel yang dibeli dengan kenyataan yang dirasakan konsumen saat membeli jasa bengkel. (2) Keinginan untuk melakukan pembelian ulang (Y1.2), adalah adanya keinginan untuk melakukan pembelian ulang produk jasa bengkel di masa datang. (3) Keinginan untuk menyarankan orang lain untuk membeli (Y1.3), adalah adanya keinginan untuk menyarankan orang lain melakukan pembelian jasa bengkel yang sama 
Louis Soemadi Bopeng. Keputusan Menggunakan Jasa Bengkel Mobil di Kabupaten Manokwari: Peran Kualitas Layanan, Faktor Individual, dan Lingkungan

Menurut Engel (2001), proses keputusan konsumen merupakan hal penting yang dilakukan konsumen dalam membeli suatu produk. Proses keputusan konsumen merupakan suatu kegiatan yang penting karena dalam proses tersebut memuat berbagai langkah yang terjadi secara berurutan sebelum konsumen mengambil keputusan.

Awater (dalam Setyowardhani, 2014) mendefinisikan pengambilan keputusan sebagai kegiatan mengumpulkan informasi tentang alternatif yang relevan dan membuat pilihan yang sesuai. Dalam proses pengambilan keputusan, konsumen memiliki sasaran atau perilaku yang ingin dicapai atau dipuaskan. Selanjutnya, konsumen membuat keputusan mengenai perilaku yang ingin dilakukan untuk dapat memecahkan masalahnya. Selanjutnya dijelaskan bahwa pemecahan masalah merupakan suatu aliran timbal balik yang berkesinambungan di antara faktor lingkungan, proses kognitif dan afektif, serta tindakan perilaku. Proses pengambilan keputusan terdiri dari empat tahapan. Pada tahap pertama merupakan pemahaman akan adanya masalah. Tahap berikutnya, terjadi evaluasi terhadap alternatif yang ada dan tindakan yang paling sesuai dipilih. Selanjutnya, pembelian diwujudkan dalam bentuk tindakkan. Pada akhirnya barang yang telah dibeli akan digunakan dan konsumen melakukan evaluasi ulang terhadap keputusan yang telah diambilnya.

\section{Kualitas Layanan}

Tjiptono (2014) mendefinisikan kualitas layanan sebagai sebuah upaya pemenuhan kebutuhan dan keinginan konsumen serta ketepatan penyampaiannya agar sebanding dengan harapan konsumen. Apabila jasa yang diterima atau dirasakan sesuai dengan yang diharapkan, kualitas layanan dipersepsikan baik dan memuaskan. Jika kualitas layanan yang diterima melampaui harapan maka kualitas layanan dipersepsikan sebagai kualitas yang ideal. Sebaliknya jika kualitas pelayanan yang diterima lebih rendah dari yang diharapkan, maka kualitas dipersepsikan buruk atau tidak memuaskan. Menurut Parasuraman (1998), kualitas layanan diukur dengan menggunakan 5 indikator, yaitu reliability, responsiveness, tangible, essurance, dan empathy.

Parasuraman (1988) menyatakan bahwa kualitas layanan memiliki hubungan yang erat dengan kepuasan pelangan dan merupakan selisih jasa yang diharapkan dengan jasa yang diterima. Apabila jasa yang diterima atau dirasakan sesuai dengan yang diharapkan maka kualitas layanan dipersepsikan baik. Pelanggan memilih para penyedia jasa atas dasar ini dan setelah menerima jasa, mereka akan membandingkan pelayanan yang dirasakan dengan pelayanan yang dikehendaki. Apabila pelayanan yang dirasakan sesuai dengan kualitas layanan yang dikehendaki konsumen dan akhirnya merasa puas, mereka akan menggunakan lagi penyedia jasa tersebut (dalam hal ini bengkel).

Nugraha (2016) membuktikan bahwa variabel kualitas pelayanan memberikan kontribusi yang besar dalam memengaruhi keputusan penggunaan jasa. Penelitian yang dilakukan oleh Parasuraman, Zeithaml, dan Berry pada (1985 dalam Parasuraman, 1988) dengan variabel kualitas pelayanan dan kinerja, didapatkan hasil bahwa Secara spesifik terdapat harapan dan persepsi pelanggan atas kualitas pelayanan yang terdiri dari 10 dimensi, yang oleh parasuraman diringkas menjadi 5 dimensi yaitu reliability, responsiveness, tangible, essurance, dan empathy. Penelitian ini terus dikembangkan oleh untuk menemukan formulasi pengukuran kualitas layanan yang bisa mewakili harapan pelanggan dan layanan yang dipersepsikan (Parasuraman, et.al., 1994). Bentuk kualitas layanan yang berkaitan dengan keputusan pembelian dikemukakan oleh Engel et.al. (2001) yang menunjukkan bahwa kualitas layanan mempengaruhi keputusan pembelian yang dilakukan oleh konsumen.

H1: Terdapat pengaruh kualitas pelayanan terhadap keputusan konsumen dalam membeli jasa bengkel.

H2: Faktor kualitas layanan merupakan faktor yang dominan memengaruhi keputusan konsumen dalam membeli jasa bengkel.

\section{Faktor Individu}

Karakteristik individu merupakan suatu proses psikologi yang memengaruhi individu/ konsumen dalam memperoleh, mengkonsumsi serta menerima barang dan jasa serta pengalaman. Faktor individu 
yang terdiri dari motivasi, persepsi, sikap dan pembelajaran merupakan faktor internal yang mengerakkan dan memengaruhi perilaku dalam proses keputusan pembelian konsumen (Engel., 2001).

Konsumsi suatu produk atau jasa adalah bagaimana individu membuat keputusan untuk membelanjakan sumber daya yang tersedia (uang, waktu, dan lain-lain) untuk kepentingan yang diinginkan setiap individu. Oleh sebab itu, keputusan tidak hanya didasarkan pada alasan rasional atau ekonomi semata, tetapi ada pengaruh lain yaitu karakteristik individu yang terdiri dari motivasi, persepsi, sikap, dan pembelajaran (Schiffman, 2004).

Penelitian Douglas \& Gordon (2000) menunjukkan adanya pengaruh pengalaman dan pembelajaran ketika proses pemilihan yang dilakukan konsumen baru pada sebuah pasar. Hasil ini juga dapat ditunjang dengan penelitian yan dilakukan oleh Widiasih (2003) yang menunjukkan karakteristik individu berpengaruh dominan terhadap pengambilan keputusan pemakaian jasa.

H3: Terdapat pengaruh faktor individual yang terdiri dari motivasi, persepsi, sikap dan pembelajaran terhadap keputusan konsumen dalam membeli jasa bengkel.

\section{Lingkungan}

Menurut Engel (2001), perilaku proses keputusan pembelian konsumen dipengaruhi oleh faktor lingkungan yang terdiri dari aspek budaya, kelas sosial, kelompok referensi dan keluarga. Penelitian yang dilakukan Young-Kyung \& Jikyeong (2001) yang membuktikan pengaruh signifikan keluarga, teman, dan teman sekerja terhadap keputusan pembelian produk. Adanya pengaruh faktor lingkungan ini juga ditunjang dengan penelitian yang dilakukan oleh Dallaert (1998) yang menjelaskan bahwa salah satu faktor yang dominan berpengaruh terhadap perilaku berbelanja dikaitkan dengan efisiensi adalah jarak tempat tinggal konsumen dengan lokasi supermarket. Jarak merupakan bagian dari aspek budaya yang merupakan nilai-nilai, norma-norma yang menjadi batasan atau kebiasaan yang dianut suatu kelompok masyarakat. Berdasarkan uraian di atas, maka dapat dikemukakan hipotesis sebagai berikut:

H4: Terdapat pengaruh faktor lingkungan yang terdiri dari budaya, kelas sosial, kelompok referensi dan keluarga; terhadap keputusan konsumen dalam membeli jasa bengkel.

\section{METODE PENELITIAN}

Penelitian ini merupakan penelitian explanatory research yang menjelaskan hubungan antara variabelvariabel melalui pengujian hipotesa. Pendekatan yang digunakan adalah pendekatan kuantitatif yang didasari oleh model hipotesa yang digunakan untuk menjawab permasalahan dan tujuan penelitian dengan menggunakan analisis statistik inferensial. Populasi penelitian ini adalah semua konsumen atau pelanggan jasa bengkel dengan karakteristik adalah konsumen yang menggunakan jasa untuk melakukan perbaikan dan perawatan kendaraan mobil/ roda empat. Pengambilan sampel dalam penelitian ini menggunakan metode convenience sampling. Jumlah sampel yang digunakan adalah sebanyak 118 responden dengan kriteria memiliki kendaraan bermotor roda empat atau lebih dan telah pernah menggunakan jasa bengkel untuk merawat atau memperbaiki kendaraannya. Metode pengumpulan data dalam penelitian ini adalah metode survey dengan menggunakan kuesioner yang terstruktur, bertujuan untuk mendapatkan informasi yang spesifik berdasarkan pertanyaan yang diajukan kepada responden. Pengukuran data yang berkaitan dengan variabel bebas dan terikat menggunakan skala Likert. Sangat setuju, diberi skor 5. Tidak setuju, diberi skor 4. Cukup Setuju, diberi skor 3. Kurang Setuju, diberi skor 2. Tidak Setuju, diberi skor 1. Metode statistik inferensial yang digunakan dalam penelitian ini yaitu analisis faktor dan analisis regresi linear berganda dengan bantuan perhitungan melalui program komputer (SPSS). 
Louis Soemadi Bopeng. Keputusan Menggunakan Jasa Bengkel Mobil di Kabupaten Manokwari: Peran Kualitas Layanan, Faktor Individual, dan Lingkungan

\section{HASIL DAN PEMBAHASAN}

\section{Hasil Analisis Regresi Linier Berganda}

Penelitian ini menggunakan teknik analisis regresi berganda dengan 3 variabel independent yaitu Kualitas Layanan (X1), Individual (X2) dan Lingkungan (X3) dan 1 variabel dependent (y) yaitu Keputusan Pembelian (Y). Hasil pengolahan data dengan menggunakan software SPSS dapat dilihat di Tabel 1. Hasil penelitian juga dapat dirumuskan dalam formula (1).

$\mathrm{ZY}=0,172 \mathrm{ZX} 1+0,331 \mathrm{ZX} 2+0,453 \mathrm{ZX} 3+e$

Tabel 1.

RINGKASAN ANALISIS REGRESI

\begin{tabular}{lccccc}
\hline \multicolumn{1}{c}{ Jenis Uji dan Variabel } & Koefisien $\boldsymbol{\beta}$ & $\begin{array}{c}\text { Standardized } \\
\text { Koefisien } \boldsymbol{\beta}\end{array}$ & $\mathbf{t}_{\text {hitung }}$ & Sig. & Keterangan \\
\hline Constant & 0,000 & & 0,000 & 1,000 & \\
Faktor Kualitas Layanan (X1) & 0,172 & 0,172 & 2,254 & 0,026 & Signifikan \\
Faktor Individual (X2) & 0,331 & 0,331 & 3,887 & 0,000 & Signifikan \\
Faktor Lingkugan (X3) & 0,453 & 0,453 & 6,531 & 0,000 & Signifikan \\
A & $=0,05$ & & & & \\
Koefisien Determinasi $\left(\mathrm{R}^{2}\right)$ & $=0,586$ & & & & \\
F-Hitung & $=53,697$ & & & & \\
F-Tabel & $=2,684$ & & & & \\
Signifikansi & $=0,000$ & & & & \\
t-tabel & $=1,981$ & & & & \\
\hline
\end{tabular}

Koefisien regresi X1 diperoleh sebesar 0,172. Hasil ini menunjukkan bahwa hubungan yang terbentuk antara $\mathrm{X} 1$ dan $\mathrm{Y}$ adalah hubungan yang searah karena koefisien regresi yang didapatkan adalah positif. Hubungan searah berarti semakin tinggi X1 maka $\mathrm{Y}$ akan semakin tinggi. Koefisien regresi $\mathrm{X} 2$ diperoleh sebesar 0,331. Hasil ini menunjukkan bahwa hubungan yang terbentuk antara X2 dan Y adalah hubungan yang searah karena koefisien regresi yang didapatkan adalah positif. Hubungan searah berarti semakin tinggi X2 maka Y akan semakin tinggi. Koefisien regresi X3 diperoleh sebesar 0,453 . Hasil ini menunjukkan bahwa hubungan yang terbentuk antara $\mathrm{X} 3$ dan $\mathrm{Y}$ adalah hubungan yang searah karena koefisien regresi yang didapatkan adalah positif. Hubungan searah berarti semakin tinggi X3 maka Y akan semakin tinggi.

Ho untuk pengujian simultan ditolak karena nilai $\mathrm{F}$ hitung lebih besar dari $\mathrm{F}$ tabel dan signifikansi kurang dari 0,05. Ini membuktikan bahwa variabel Faktor Kualitas Layanan (X1), Faktor Individual (X2) dan Faktor Lingkungan (X3) secara bersama-sama berpengaruh signifikan terhadap Keputusan Pembelian (Y).

Variabel independen Faktor Kualitas Layanan (X1), Faktor Individual (X2) dan Faktor Lingkungan (X3) memiliki pengaruh yang signifikan. Ini karena nilai signifikansi yang lebih rendah dari 0,05 dan nilai thitung yang lebih tinggi dari t-tabel.

Hasil koefisien determinasi menunjukkan persentase besarnya sumbangan atau kontribusi dari variabel bebas Faktor Kualitas Layanan (X1), Faktor Individual (X2) dan Faktor Lingkungan (X3) terhadap Keputusan Pembelian (Y) adalah sebesar 57,5\% atau besarnya keragaman Keputusan Pembelian (Y) dapat dijelaskan oleh variabel Faktor Kualitas Layanan (X1), Faktor Individual (X2) dan Faktor Lingkungan (X3) adalah 57,5\%. Sedangkan sisanya sebesar 42,5\% dijelaskan faktor lain yang tidak diteliti atau error. 


\section{Pembahasan}

Lingkungan terbentuk dari indikator budaya, kelas sosial, kelompok referensi dan keluarga. Berdasarkan hasil analisis faktor, dijelaskan bahwa indikator yang memberikan kontribusi paling tinggi terhadap Faktor Lingkungan (X3) adalah Pengaruh Teman (X3.3). Jika seorang konsumen belum memiliki pengalaman mengenai sebuah usaha jasa, maka konsumen tersebut cenderung untuk mencari referensi dari orang terdekat, salah satunya adalah teman.

Menurut Kotler (2005), kelompok referensi memengaruhi perilaku seseorang dalam pembelian dan sering dijadikan pedoman oleh konsumen dalam bertingkah laku. Anggota referensi sering menjadi penyebar pengaruh dalam hal selera. Artinya jika orang yang dijadikan referensi tersebut memiliki pengalaman yang baik terhadap usaha bengkel, maka dia akan menceritakan pengalamannya kepada konsumen lain dan menganjurkan untuk menggunakan jasa bengkel yang sama. Namun, seandainya referensi tersebut memiliki pengalaman yang buruk terhadap usaha jasa bengkel, maka dia akan cenderung untuk mencegah konsumen lain untuk menggunakan usaha jasa bengkel.

Artinya bahwa faktor yang memiliki pengaruh terbesar terhadap keputusan penggunaan jasa suatu bengkel di Manokwari Papua Barat adalah faktor lingkungan. Factor lingkungan yang terjadi di manokwari karena rasa solidaritas dan kepedulian antar sesama masyarakat di Manokwari masih tinggi dan kuat. Sehingga, solidaritas dan kepedulian adalah factor lingkungan yang ikut berperan penting dalam pengambilan keputusan pembelian pada masyarakat manokwari, khususnya para pemilik kendaraan mobil. Di mana, banyak pemilik kendaraan mobil mengikuti komunitas mobil yang sama dan saling memberikan informasi terkait bengkel yang menjadi langganan atau mendapatkan penilaian baik dan buruk berdasarkan pengalaman yang dialami.

Berdasarkan hasil bahwa faktor lingkungan dominan berpengaruh, maka Usaha bengkel di manokwari harus mampu menangani keluhan dari konsumen, baik keluhan dalam hal permasalahan yang dihadapi konsumen maupun keluhan dalam hal pelayanan, dapat memengaruhi konsumen tersebut menggunakan jasa yang ditawarkan. Apabila keluhan dari konsumen tidak ditangani dengan baik, dapat berakibat pada beralihnya konsumen tersebut kepada usaha bengkel lain dan pengalaman yang dialami akan diceritakan kepada kerabat lain.

Namun sebaliknya jika keluhan konsumen tersebut ditangani dengan baik oleh setiap pemilik usaha bengkel dan mampu memberikan kepuasan, maka konsumen memiliki pengalaman yang baik terhadap jasa yang diberikan oleh usaha bengkel. Pengalaman baik akan dibagikan kepada orang sekitar yang memerlukan jasa usaha bengkel dan secara tidak langsung, akan ikut menambah konsumen pada usaha bengkel yang memiliki penilaian baik oleh seorang konsumen.

\section{KESIMPULAN}

Hasil penelitian membuktikan bahwa kualitas layanan berpengaruh terhadap keputusan pembelian konsumen. Apabila pelayanan yang diberikan melebihi harapan yang merupakan keinginan konsumen, maka mereka akan menggunakan lagi produk jasa tersebut. Konsumen akan cenderung mengambil keputusan pembelian di toko yang memiliki kenyamanan ketika berbelanja dan karyawan yang ramah terhadap konsumen.

Hasil penelitian juga membuktikan bahwa faktor individual berpengaruh terhadap keputusan pembelian konsumen. Pengetahuan yang bersumber dari pengalaman pribadi seorang konsumen, dapat mempengaruhi keputusan konsumen dalam memilih usaha jasa bengkel. Seandainya keluhan konsumen tersebut ditangani dengan baik dan mampu memberikan kepuasan, maka konsumen memiliki pengalaman yang baik terhadap jasa yang diberikan kepadanya. Namun sebaliknya, jika konsumen pernah mengalami penanganan yang buruk dan berakibat ketidakpuasan, akan menimbulkan pengalaman yang buruk dan konsumen tidak lagi memilih usaha jasa tersebut. 
Louis Soemadi Bopeng. Keputusan Menggunakan Jasa Bengkel Mobil di Kabupaten Manokwari: Peran Kualitas Layanan, Faktor Individual, dan Lingkungan

Faktor lingkungan terbukti berpengaruh terhadap keputusan pembelian konsumen Jika seorang konsumen belum memiliki pengalaman mengenai sebuah usaha jasa, maka konsumen tersebut cenderung untuk mencari referensi dari orang terdekat, salah satunya adalah teman.

Di antara faktor kualitas layanan, individu dan lingkungan, yang paling dominan berpengaruh terhadap keputusan pembelian adalah faktor lingkungan yang terdiri dari budaya, kelas sosial, kelompok referensi dan keluarga. Hal ini diangap rasional bagi peneliti karena Tingginya rasa solidaritas dan kepedulian antar sesama masyarakat manokwari berperan penting dalam pengambilan keputusan pembelian mereka. Pendapat dari teman menjadi acuan utama dalam pengambilan keputusan jasa bengkel karena mereka mengasumsikan bahwa terman atau kelompok referensi telah pernah mengunjungi bengkel dan mereka mengangap bengkel tersebut mampu memenuhi harapan mereka.

Rekomendasi untuk penelitian selanjutnya yaitu bisa melakukan penelitian pada jenis usaha jasa lainnya, apakah hasil pada penelitian ini bisa di generalisasikan pada usaha jasa secara umum atau berlaku untuk usaha jasa bengkel. Terlebih di Manokwari memiliki usaha jasa yang heterogen dengan skala yang berbeda-beda.

\section{DAFTAR PUSTAKA}

Amirullah. (2002). Perilaku Konsumen, cetakan pertama. . Jakarta.: Graha Ilmu, .

Dallaert, Benedict. (1998). Investigating Consumers Tendency to Combine Multiple Shopping Purposes and Destinations, . Journal of Marketing Research, Vol. XXV: 177-178.

Dinawan, Muhammad Rhendria (2010). Analisis Faktor-Faktor Yang Mempengaruhi. Jurnal Sains Pemasaran Indonesia Volume IX, No. 3, Desember, 335-369.

Douglas and Gordon. (2000). The Evolution of Brand Preferences and Choise Behavior of Consumers New to a Market. Journal of Consumer research. Volume: 37 (2), 139-155.

Fatihudin, Didin. (2019). Pemasaran Jasa (Strategi, Mengukur Kepuasan, dan Loyalitas Pelanggan). Yogyakarta: Deepublish.

Engel., F. J. (2001). Costumer Behavior. 8 th Edition (terjemahan). Jakarta: Penerbit Binarupa Aksara.

Jaya. (2005). Pengaruh Perilaku Nasabah Terhadap Keputusan Pembelian Produk Sepatu di Industri Dragon Mojokerto. . Malang: Thesis, Pasca Sarjana Universitas Brawijaya,.

Kotler, P. (2005). Marketing Management. 11 th Edition. New Jersey: Prentice Hall Inc.,.

Lovelock, C. ( 2002). Service Marketing and Management. . New york: Second Edition Prentice Hall.

Malhotra, N. K. (1999). Marketing Research: An Applied Orientation. Third Edition. New Jersey, USA: Prentice Hill Inc.

Mowen, J. C. (2001). Consumer Behavior. Lina Salim (penerjemah) Perilaku Konsumen Jilid I,. Jakarta: Penerbit Erlangga.

Nancy J. Miller, e. a. (1997). Factor Contributing to in Shopping Behavior in Rural Trade Areas: Implications for Local Retailers. Jurnal of Small Bussiness Management, Vol. 35, 172-178. 
Nugraha, D. K. (2016). Pengaruh Harga dan Kualitas Pelayanan terhadap Keputusan Penggunaan Jasa Bengkel PT. Astra International Tbk-Daihatsu Majapahit Semarang. Diponegoro, Journal of Social And Politic Of Science Volume 5, Nomor 4, 1-8.

Nurcaya, K. I. (2013). Pengaruh Dimensi Kualitas Pelayanan Jasa terhadap Kepuasan Pelanggan D\&I Skin Centre Denpasar. e-Jurnal Manajemen Vol 2 No 8, 918-937.

Parasuraman, A. Z. (1988). SERVQUAL: A Multiple Item Scale for Measuring Consumer Perceptions of Service Quality . Retailing, 64(1), 12-40.

Poerwanti, E. (1998). Dimensi-Dimensi Riset Ilmiah. Malang: Pusat Penerbitan Muhammadiyah.

Purba, A. S. (2019). Analisis Strategi Bersaing Dalam Persaingan Bisnis Properti Residensial (Rumah Tinggal) Di Kota Manado. Jurnal Riset Bisnis dan Manajemen Vol.7 No.4, 381-392.

Santoso, S. d. (2004). Riset Pemasaran Konsep dan Aplikasi dengan SPSS. Jakarta: PT. Elex Media Komputilindo.

Sasmito, N. d. (2013). Faktor Internal dan Eksternal terhadap Keputusan. Jurnal Manajemen dan Akuntansi Volume 2, Nomor 1, April , 85-100.

Schiffman, L. G. (2004). Consumer Behavior. New Jersey: Prentice Hall, Seventh Edition,.

Setyowardhani, T. E. (2014). Perilaku Konsumen. In: Pemahaman Konsep dan Studi Perilaku Konsumen dalam Pengembangan Strategi Pemasaran. Jakarta: Universitas Terbuka.

Stanton, W. J. (2002). Fundamentals of Marketing. 10 th Edition. Singapore: Mc Graw-Hill International.

Sugiyono. (2004). Metode Penelitian Bisnis. . Bandung: Alfabeta.

Suzanto, B. (2011 ). Pengaruh Kualitas Jasa Pelayanan terhadap Kepuasan Pasien pada Rumah Sakit Umum Kota Banjar. Jurnal Ekonomi, Bisnis \& Entrepreneurship Vol. 5, No. 1, 28-44.

Tjiptono, F. (2009). Strategi Pemasaran, Edisi kedua, Cetakan ketujuh. Yogjakarta: Andi Offset.

Tjiptono, F. (2014). Pemasaran Jasa - Prinsip, Penerapan, dan Penelitian. Yogyakarta: ANDI.

Widiasih, N. N. (2003). Analisis Faktor-Faktor Perilaku Konsumen dalam Pengambilan Keputusan Pemakaian Jasa Warnet di Denpasar Bali. Malang.: Thesis, Pasca Sarjana Universitas Brawijaya, .

Wirtz., M. a. (2006). The Role of Store Environmental Stimulation and Social Factors on Impulse Purchasing. Journal of Services Marketing 22(7):562-567

Young-Kyung K and Jikyeong K. (2001). The Effent of Etnicity and Product Purchase Decision Making,. Journal of Consumer Research. Volume 41 (March/April), 134-139.

Zeithaml, A. V. (2003). Service Marketing: Integrating Costumer Focus Across the Firm. Third Edition,. New York.: McGraw. Hill 